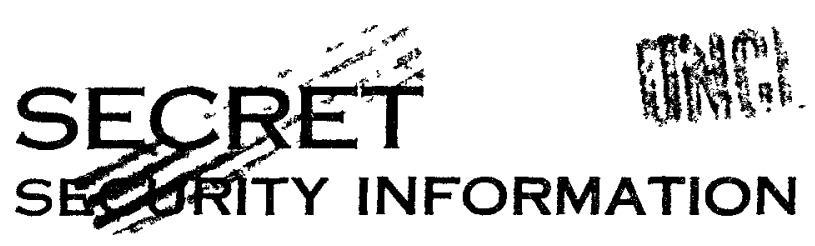

\title{
FINAL REPORT PRODUCTION TEST 235-6 BRIQUETTING OF MACHINED PLUTONIUM TURNINGS FOR RECYCLE TO THE CASTING OPERATION
}

BY

B. A. CHANDLER

TECHNICAL SECTION

ENGINEERING DEPARTMENT

NOVEMBER 7,1952

\begin{abstract}
RESTBICTED DATA
THIS DOCUMENT EONTAINS RESTRICTED DATA AS DEFINED IN THE ATOMIC ENERGY ACT OF 1946. ITS TRANSMITTAL OR THE DISCLOSURE OF ITS CONTENTS IN ANY MANNER TO ANY UNAUTHORIZED PERSON", LS PROHIBITED.
\end{abstract}

\section{NUCLEONICS DIVISION RICHLAND, WASHINGTON}

\section{GENERAL ELECTRIC}




\section{DISCLAIMER}

This report was prepared as an account of work sponsored by an agency of the United States Government. Neither the United States Government nor any agency Thereof, nor any of their employees, makes any warranty, express or implied, or assumes any legal liability or responsibility for the accuracy, completeness, or usefulness of any information, apparatus, product, or process disclosed, or represents that its use would not infringe privately owned rights. Reference herein to any specific commercial product, process, or service by trade name, trademark, manufacturer, or otherwise does not necessarily constitute or imply its endorsement, recommendation, or favoring by the United States Government or any agency thereof. The views and opinions of authors expressed herein do not necessarily state or reflect those of the United States Government or any agency thereof. 


\section{DISCLAIMER}

Portions of this document may be illegible in electronic image products. Images are produced from the best available original document. 


\title{
UNCLASSFFED
}

$-1-2-$

HW-26141

\section{AEC RESEARCH AND DEVELOPMENT REPORT}

\author{
FINAL REPORT \\ PRODUCTION TEST 235-6 \\ BRIQUETTING OF MACHINED PLUTONIUM TURNINGS \\ FOR RECYCLE TO THE CASTING OPERATION \\ By \\ B. A. Chandler \\ Process
Separations Technology Unf tFor The Atomic Energy Commission \\ November 7, 1952 \\ HANFORD WORKS \\ RICHLAND, WASHINGTON \\ CLASSIFICATION CANOELLED \\ DATE MAR 151960

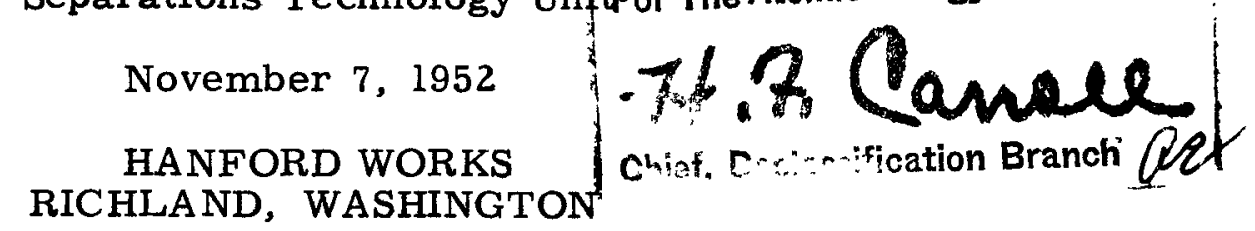

Operated for the Atomic Energy Commission by the

General Electric Company under Contract \#W-31-109-Eng-52

\begin{tabular}{l} 
Photostat Charge \$1.70 for \\
Access Permittees \\
Available from \\
Technical Information Service \\
P. O. Box 1001, Oak Ridge, Tennessee \\
\hline
\end{tabular}
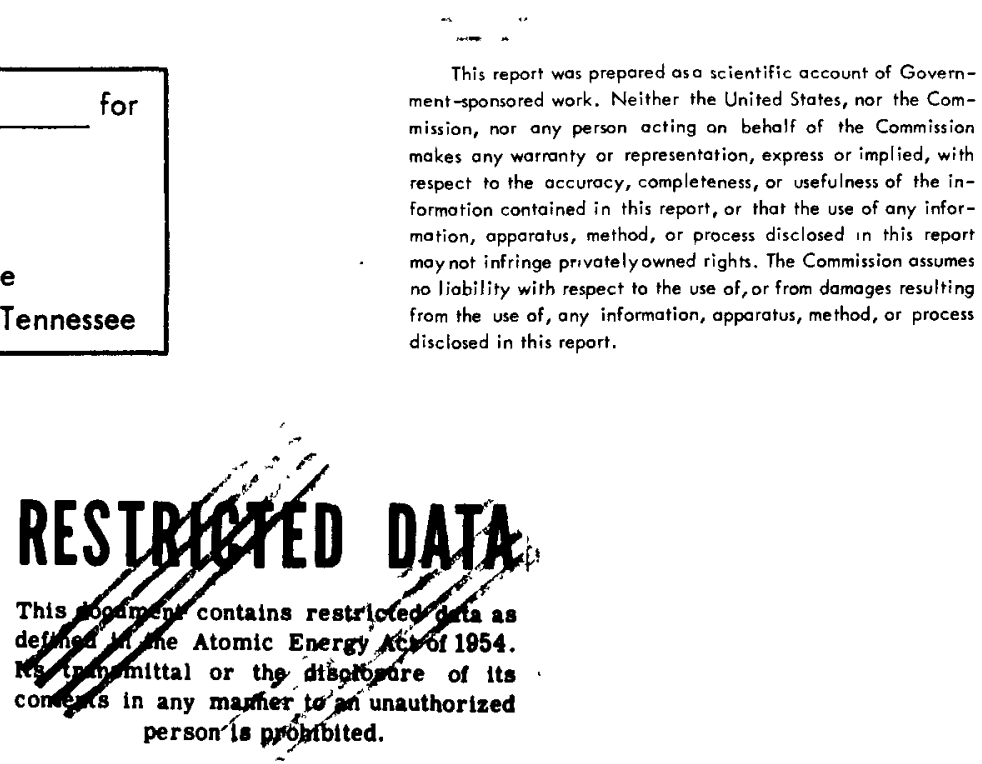
C. N. Gross - J. E. Maider, Jr.

A. B. Greninger - R. H. Beaton

O. H. Greager - W. K. Woods

R. S. Bell - V. R. Chapman

T. Prudich

L. M. Meeker - S. G. Smolen

R. B. Richards - J. B. Work

W. N. Mobley - O. F. Beaulieu

T. W. Hauff

F. W. Albaugh

V. R. Cooper

R. W. Benoliel - B. A. Chandler -

R. E. Isaacson - File PD-1

W. K. MacCready

700 Extra

700 File

300 File

Yellow Copy

\section{EXTERNAL DISTRIBUTION}

$18-19$

20

$21-25$

26

$27-30$

31

32

33

$34-48$

Atomic Energy Commission, Washington

Chicago Patent Group

duPont Company

Hanford Operations Office

Knolls Atomic Power Laboratory

Patent Branch, Washington

Savannah River Operations Office, Augusta Savannah River Operations Office, Wilmington

Technical Information Service, Oak Ridge

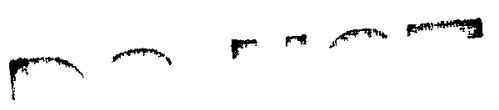




\author{
FINAL REPORT \\ PRODUCTION TEST 235-6 \\ BRIQUETTING OF MACHINED PLUTONIUM TURNINGS \\ FOR RECYCLE TO THE CASTING OPERA TION
}

\title{
I. INTRODUCTION
}

Plutonium turnings that are formed in the machining of castings into core components are normally recycled to the reduction operation. At the site of the reduction operation, the turnings are placed in a reduction bomb with plutonium fluoride powder and other essential materials. The subsequent reduction of the powder and the melting of the turnings form a button of a size and shape workable for further processing. Turnings are normally recycled to the reduction operation within a few days after they are produced. At times, however, operating sequences become skewed, and turnings are collected in quantities greater than can be immediately recycled to reduction. Undesirable turning storage times of a few weeks may then occur before causes responsible for turnings accumulation are reversed and normal inventories are attained. It is, therefore, desirable to have an alternate method of depleting a large turnings inventory in a short period of time.

Several possible alternatives for intermittently reprocessing turnings other than recycling them to the reduction operation have been considered and the most feasible of these are:

1. Briquetting of turnings for recycle to the casting operation.

2. Hydrofluorination of the turnings (Production Test 234-7 inactive).

3. Recycling the turnings to the Skull Recovery equipment.

Recycling turnings to the casting operation offered a means whereby a minimum amount of reprocessing could be achieved in a minimum amount of time. Unsuccessful attempts had been made, previous to this test, to recycle turnings to the casting operation in the loose form. The 
loose turnings placed in a pouring crucible did not pour, but formed a sintered mass not suitable for routine use. The tenacity of the oxide film on the turnings was sufficient to prevent the coalescence and pouring of the metal.

By pressing the turnings into a compact mass, better heat transfer, more intimate contact of the molten metal, less oxidation of the turnings, possible rupture of oxide films that had formed, and the combination of a larger quantity of turnings into a single mass should be achieved. Briquetting of turnings for casting would increase the production capacity of the reduction equipment since all the plutonium permissable within the critical mass limitations for this operation could be in the form of plutonium tetrafluoride powder. Production Test $235-6^{(1)}$ was initiated to evaluate briquetting and casting procedures in production equipment.

II. OBJECTIVES

The objectives of the production test were:

A. To test an alternate procedure for reworking the plutonium turnings from the machining operation.

B. To evaluate castings made from briquettes as to:

1. Casting yields obtained from melting and pouring briquettes.

2. Homogeniety of the casting (voids and 70-58 segregation).

3. Purity of the casting.

4. Machineability.

\section{SUMMARY AND CONCLUSIONS}

Eight castings made from three briquettes each were processed using RG Line equipment for pressing the briquettes. Of the eight, six passed final inspection. One machined piece was recast, after two coating failures with subsequent stripping had caused the piece to be undersized. The other casting was too small to machine due to an incomplete pour caused by an interruption in the casting cycle and was combined 
with a button and recast. The castings successfully processed to final inspection were comparable to castings produced from plutonium buttons.

Loss to skulls from casting of briquettes (omitting the casting that was too small to machine) ran from 10 to 11 per cent as compared to a skull loss of 2 to 3 per cent for castings made from buttons.

The average plutonium content for five of the castings for which plutonium assays were made was 98.88 per cent, the lowest being 98.68 per cent. No voids were found in the castings and 70-58 homogeneity was better than the average of normally processed material. Operators reported that the castings made from briquettes machined easier than normal castings. The material appeared to be softer and very little sparking was noted during the machining operations at either lathe.

It was concluded that briquetting of turnings for recycle to the casting operation is an acceptable method of reworking plutonium turnings. The principal disadvantage being that relatively large skulls are e ncountered.

IV. RECOMMENDATIONS

In view of the production test results, it is recommended that briquetting of plutonium turnings and their recycle to the casting operation be considered an acceptable method of reworking turnings.

In the event that briquetting of turnings should be adopted for more than occasional use, it is recommended that a simpler design of the punch and die and of the evacuation and purging equipment be developed. In order to permit pressing the briquette in one operation a press $w$ ith a stroke of 8 to 10 inches is desirable.

V. EXPERIMENTAL

A small die and punch assembly as illustrated by Figure 1 was fabricated to press turnings into briquettes $2-1 / 2$ inches in diameter and 


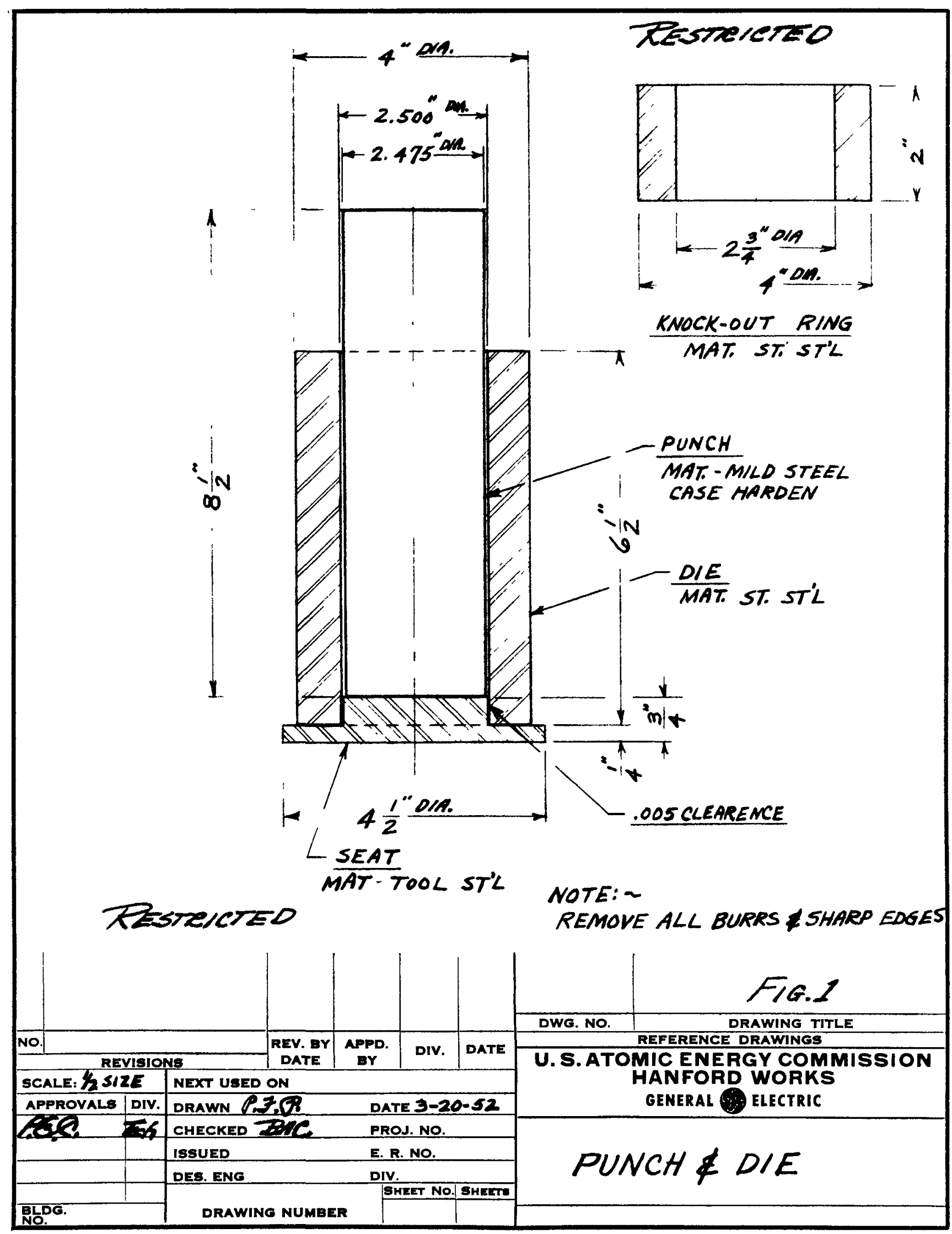

FORM NO 1.34.ES-LAH CO. 6.51 
approximately $1 / 2$ inch thick. When pressed at $20,000 \mathrm{lbs} / \mathrm{sq}$. in., a briquette of this size can be compressed to about 25 per cent voids or a bulk density of approximately 12 from an initial bulk density of the uncompressed mass of turnings of approximately 2.0. A maximum of 25 per cent voids was established due to the limited volume of the pouring crucible. Further compression would have required an additional presspunch and a third pressing operation. The latter would have resulted in an uneconomic expenditure of operator time and the effect of further compression of turnings was not evaluated. The turnings were loaded into the die in Hood 18 of the RG Line. The die was loaded, using the punch for tamping, to just below the halfway point, with a constant play of helium into the die to prevent sparking. The die and punch assembly with the turnings was then transferred to Hood 19 where it was placed in a press can that had been used when the RG Line process included a pressing operation. The press can was moved into position under the 300 ton press and connected to the existing helium and vacuum lines. The can was evacuated and purged with helium twice. A small helium positive pressure was maintained in the can during pressing to prevent air from entering the can. Because of the limited travel (3 inches) of the 300-ton press and the press can bellows, the briquettes had to be pressed in two stages. After pressing the turnings to about one-half of their hand tamped volume, it was necessary to disconnect the vacuum and helium lines from the can, move the can from beneath the press, open the can, place a spacer block on top of the punch, reconnect the apparatus and press the briquette a second time. After the second pressing, the briquette was removed from the die in Hood 18 under the helium atmosphere to prevent sparking. The time required to press a briquette using this equipment was about $1-1 / 2$ hours. With equipment designed especially for briquetting turnings, the time required to press a briquette could be reduced to 15 - 20 minutes. Three briquettes were then recycled to the casting operation and processed according to standard runbook procedure. 
Sparking was less than normal during machining in both of the lathe operations. The reason for this is not known and could best be determined in metallurgical laboratory equipment.

Table I presents the data obtained for the eight castings made from briquettes.

\section{PROPOSED BRIQUETTING PROCESS}

The process and equipment for briquetting turnings may be modified for more efficient production use by the following:

1. Press the turnings of one machined piece into one briquette immediately after machining to prevent excessive oxidation.

2. Cast the briquettes as soon as possible with buttons of sizes large enough to give the desired casting weight (Buttons to be placed on top of the briquette in the pouring crucible).

3. Redesign and briquette punch and die assembly for ease in handling.

4. Design an evacuation and helium purge chamber in which the briquettes would be pressed, that would be stationary in the press and incorporate "fast acting" hose couplings.

5. Modify a small press, such as the stripping press that was used to removed shapes from the die in the retired Task VI - RMA Line equipment, for pressing the briquettes. This is a 60 ton press and 50 tons is sufficient to press the briquettes.

Advantages in the above proposed process include:

1. A better casting yield from briquettes for two reasons:

a. There would be less oxidation of the turnings because of a shorter period of time before briquetting and casting.

b. The molten button material should ajd in breaking the oxide film of turnings as it pours through the briquette. 
TABLE I

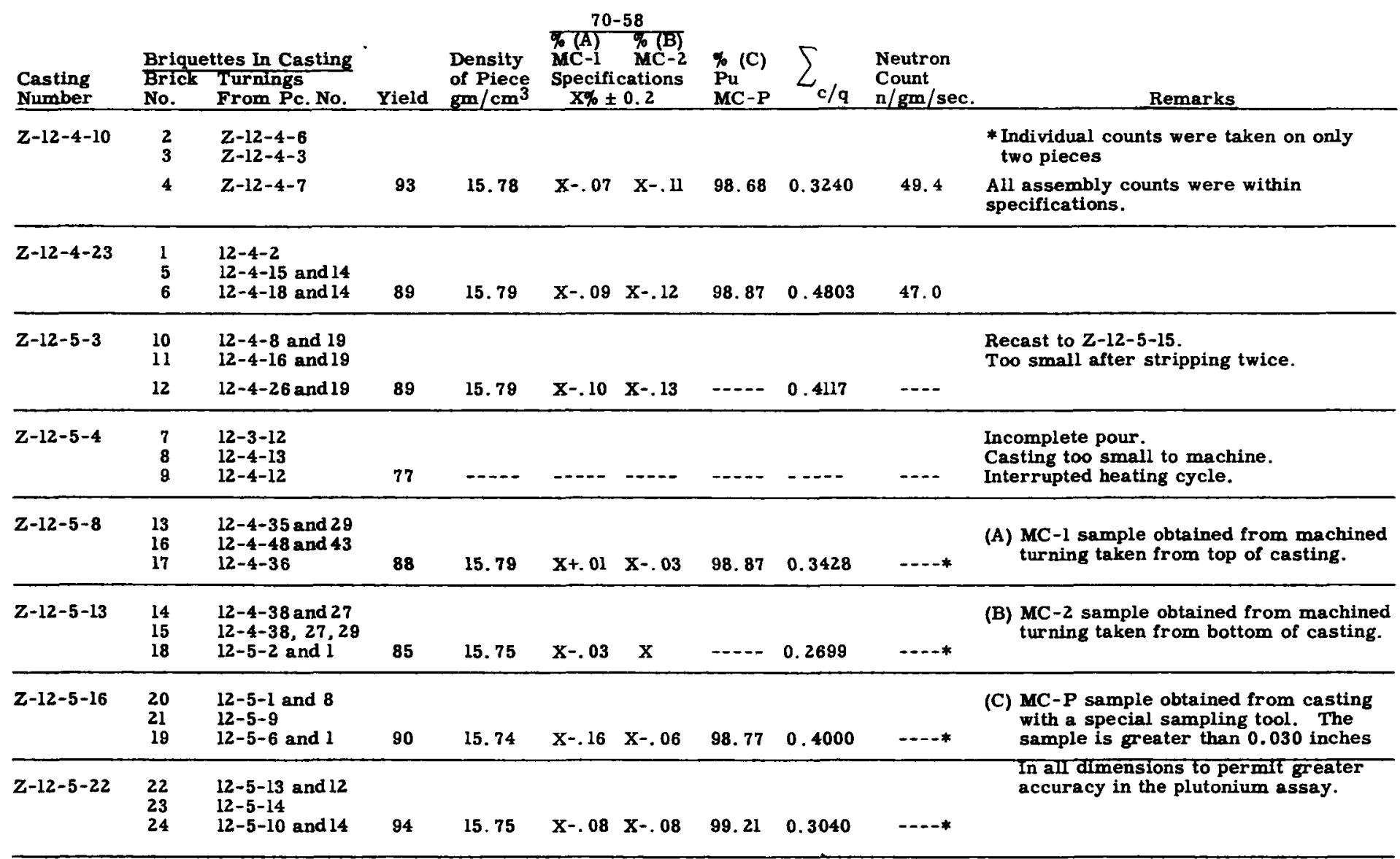


2. A savings in the number of reduction crucibles by one-third for the 110 casting.

3. A saving of Task III operator and equipment time of approximately 33-1/3 per cent.

4. A one-third increase in the capacity of the reduction equipment could be realized by eliminating recycled turnings and thereby

- increasing the amount of plutonium fluoride that could be charged per reduction by as much as 50 per cent.

On the basis of the above advantages, it is suggested that this process be given further consideration.

\section{REFERENCE}

1. HW-23899, P. E. Collins by B. A. Chandler and R. E. Isaacson, Production Test 235-6, Briquetting of Machined Plutonium Turnings for Recycle to Casting Operation, March 24, 1952.

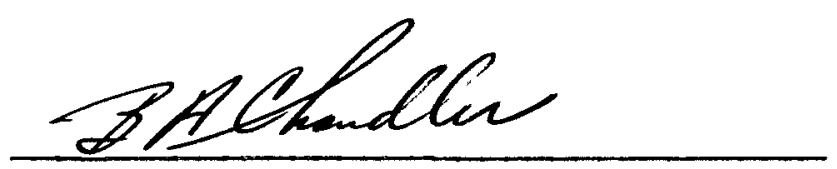

B. A. Chandler

$B A C: 1 j$ 


\section{ABSTRACT}

Twenty-four briquettes of plutonium turnings were pressed at $20,000 \mathrm{lbs}$. /sq. in. in a helium atmosphere and made into eight castings. Six castings were processed to final form and were comparable to normally processed material: Two castings were recycled due to causes other than briquetting. Casting yields, $\frac{\text { (Wt. of casting })}{\text { (Wt. of briquettes) }}$, were approximately $90 \%$; approximately $10 \%$ of the plutonium in the briquettes remaining in the melting and pouring crucible as skull. 